\title{
Corporate governance in Africa's public sector for sustainable development: The task ahead
}

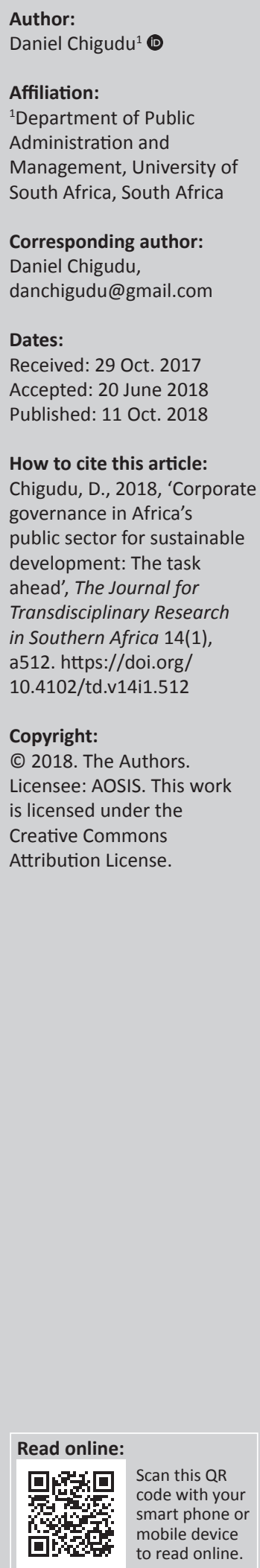

Investors around the world place emphasis on good corporate governance. This makes it imperative for the integration of good governance into corporate governance for sustainable development in Africa. There is a high mix of business with state politics in most African countries, whereby ownership is in most cases concentrated around top political elites. As a result, other stakeholders and minority shareholders often lack adequate institutional and legal protection, while managers are unable to fully exercise their mandate or do not bear the full costs of their actions. Also, even though corporations adopt international accounting standards, they hardly put them into practice breeding managerial deficiencies and abuse of discretion pervasive on the continent. Interpretivist or constructivist approach informed this study through a desktop research. An interrogation of the corporate governance principles in the public sector of selected countries in West Africa and Southern Africa was performed as prompted by the results of the various indices. Results reveal that 'excessive' political decisions are handed down to public officials as directives from political bigwigs. Good corporate governance must play a role in aligning the interests of politicians, bureaucrats and the electorate. An implementation framework is developed and recommended for sustainable development as the task ahead.

\section{Introduction}

The African Union Commission (AUC 2015:11) outlined seven aspirations for the 'Africa We Want' in its first 10-year implementation plan 2014-2023. While all aspirations are fundamental, this article focuses on Aspiration 1 on 'A prosperous Africa based on inclusive growth and sustainable development' and Aspiration 3 on 'An Africa of good governance, democracy, respect for human rights, justice and the rule of law'. This article's thrust is on good corporate governance in the public sector as the task ahead of Africa for sustainable development to be realised. African Good Governance Network (AGGN 2010) notes that governance in Africa has hinged mainly on governments and politics. However, in general, governance should not be about politics and governments according to World Bank (WB) as cited in the Venice Commission (VC 2011). Besides other institutions, the state (government) and the people (the governed) represent two actors identified within governance. As such, it is the responsibility of governments to inspire and propel the governed for sustainable development. Yet, most African governments appear to have proved to be such bad examples in this regard.

The civil society, other citizens and the private sector being the governed must not usurp undue advantage of weaknesses of the government or vice versa (Grzeszczak 2015). It is incumbent upon the governed to be proactive and have the will to stay on the course no matter how tough it may be, even if the ship of government is wobbling. The governed must make use of available tools such as citizenship participation, vision and access to information for them to fulfil their responsibilities within the domain of governance. Perhaps, if Africa must attain sustainable development, good governance should be comprehensively viewed through a lens wider in scope instead of the narrow political and economic views which have overshadowed other important aspects of the lives of the African people. Because of the unique stance on promoting feasible and viable governance that benefits all within and outside the African continent, the African Good Governance Network has sought to define good governance in such a way as to provide protection for all Africans and not limiting its adherence to African governments (AGGN 2010). Rather, Africans ought to adopt genuine expressions of opinion, affection and passion on matters relating to Africa. From an African perspective, good governance must extend to family, clan, ethnic and general cultural values among others. 


\section{Background}

While there is no universally agreed-upon definition for the term 'public sector governance' as argued by the Chartered Institute of Public Finance and Accounting in collaboration with International Federation of Accountants (CIPFA \& IFAC 2013), examples of bad corporate governance spread across Africa. To provide the social value and articulate the knowledge gap, the study focussed more on West Africa and Southern Africa examples.

For instance in 2016, Africa witnessed the remarkable redress of two disasters that had wreaked havoc in West Africa. African states in collaboration with international development partners and civil society won the first battles, and prospered in terminating the outbreak of Ebola (disease) in Sierra Leone, Liberia and Guinea. The World Health Organization (WHO) declared on 29 March 2016 that the crisis is over. Although much remains to be accomplished, remarkable strides have been taken to safeguard Lake Chad Basin against Boko Haram's threats. While these threats remain, areas initially vanquished by Boko Haram have since been reclaimed by governments. In this epoch, states ought to make an introspection on the operational issues that gave rise to these disasters to intensify, not discounting good corporate governance. This includes preventive measures to ensure a repeat of the same does not happen, or if it does, putting in place mechanisms of expeditious reactions. The emergency of both Boko Haram and Ebola in completely dissimilar geographical locations jointly share analogous governance topographies as highlighted below (Jobbins 2017):

Persistence of local discontentment over the centreperiphery divide amidst economic growth

The two calamities stood to be multifaceted regional threats manifesting in the fringes of comparatively wealthy African countries, yet in the midst of inhabitants with deep rooted suspicion of their national governance. According to the WB's World Development Indicators (WDI 2016) statistical year book, the outbreak of Ebola occurred in the forestry region of Guinea. Historically, part of the globe's richest iron mines are known to be situated there, but ironically where some cultural and minority ethnic groups have been traditionally relegated benefiting little if any from their region's huge naturally endowed mineral wealth. About a couple of months preceding the Ebola's outbreak, there were ethnic riots experienced in the region. The skirmishes were against strangers wandering in the region and were perceived to be beneficiaries of the state indulgence (Jobbins 2017). These skirmishes spread rapidly to neighbouring areas that shared similar cultures, ethnicities and landscapes. One of the poorest areas called Maiduguri in Nigeria hold the origins of Boko Haram. Boko Haram emerged here, where desertification is more pronounced with wrecked infrastructure and less hope to stir social and economic prospects for the youths.
The escalation of the crises and reaction by the international community

Security and healthy concerns in the African continent can hardly be separated from world concerns. This appears to have been confirmed in the last 4 years or more to be true (WDI 2016). It is therefore worthwhile to note that the two crises got stimulated partly by external exigencies not located in the region. That is, whether the spread of Ebola to West Africa, the influence of government failure in Libya on weapons accessibility through the Sahel, or the international extremist groups such as ISIS's amplified action. Boko Haram eventually claimed loyalty to this group. Although horrors of world extremism and epidemics activated international concerns or prompted a momentous response, those uncertainties also overturned the economic gains of a region battling to throw away an appearance of bad governance and civil unrest later diminishing tax revenue and constraining government budgets.

\section{Late adoption of society-wide approach to the management of a crisis}

The ineptitude shown during the first response to Ebola coupled with the speedy rise of Boko Haram is testament to flaws attributed to responses by national governances to crises. It can be argued that such ineptitude and mistrust among communities paved way for the Ebola affected areas' populace to maim and attack health employees. Strangely, this continued for 18 months after the outbreak despite efforts by the health personnel made to ameliorate the situation. The surrounding area including Nigeria witnessed mishandlings by armies in countering the Boko Haram's recruitment drive when the insurgence began. Also, the operations to combat terrorism were masked with clandestineness. Notably, government together with security operatives deployed in North East Nigeria did not hold meetings publicly to share security concerns in the vulnerable areas up until the midyear 2015 (WDI 2016).

Notwithstanding this distrust and the first flaws in the state reaction, neither calamity could have been appropriate for the nature of a considerable United Nations synchronised deployment of peacekeeping troops or organisations to swap fragile states that patronised areas such as South Sudan, the Eastern Democratic Republic of Congo or the Central African Republic. The reaction upturned the pattern in the crises, only after strategies by the government included direct involvement of other players such as civil society, faith-based organisations and traditional leaders.

Many similar governance issues reside in African states as those noted above. The task ahead for sustainable development on the continent is primarily located in good corporate governance of all spheres of governance institutions. The European Commission for Democracy through law CDL-AD-2011-009, a document published in 2011 by the VC, traces the origins of the notion of good governance and reports that the concept is a very old one traced in the works of Aristotle, who referred to good 
governance to describe a state ruled by an ethical and just governor. But in recent times:

governance has been used increasingly to define the process of decision-making and implementation of decisions in a variety of contexts, such as corporate governance, international governance, national governance and local governance. (VC 2011:3)

In the late 1990s, the WB established a link between the quality of a country's governance system and its ability to pursue sustainable economic and social development. The WB cited in the VC (2011:3) describes governance as encompassing the form of political regime; the process by which authority is exercised in the management of a country's economic and social resources for development; and the capacity of governments to design, formulate and implement policies and discharge functions. Hence, the WB endorses good governance as a core element of its development strategy.

\section{The study objective}

A key corporate governance objective in the public sector is providing an enabling environment and effective regulatory framework for economic activities. The study sought to plug the gap on poor corporate governance in Africa's public sector for sustainable development to be achieved.

\section{Gap analysis}

Although governance quality is cumbersome to measure with precision, the new paradigm has been the use of proxy measures for governance capabilities. These include the rule of law and the stability of property rights (Halberstam \& Stein 2009). Such proxies involve measures like counting the number of corruption cases brought to court and those measures that use survey data from credit risk agencies. The agencies conduct perception surveys and experience of different aspects of governance from the business community. The World Wide Governance Indicators (WGIs) are the most well-known of these data sets as produced by the WB although some other data sets are now available. Most countries in Africa perform badly on the key areas of concern of the good governance agenda in terms of these measures (IIAG 2017). For instance, the WGI indicators place the majority of African countries in the bottom 50th percentile of their six dimensions of governance. According to the WB (2008), this means that Africa performed worse than any other region, except the former Soviet Union. Also, with respect to the Corruption Perceptions Index (CPI) produced by Transparency International (TI) in Africa, 30 out of the 47 were found to have rampant corruption and only three, Botswana, Cape Verde and Mauritius, scored above the global average for corruption (TI 2008).

For the renewal of the continent, the practice of good corporate governance in the public sector is essential. Current deficiencies or gaps located in corporate governance structures of Africa indicate the urge to help Africa move forward economically.

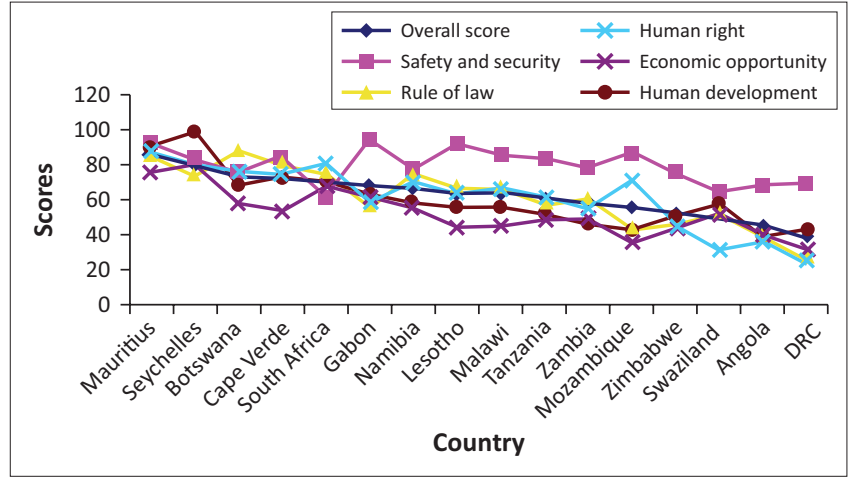

Source: IIAG 2007

FIGURE 1: Ibrahim index of African Governance.

This is crucial because, among other things, good corporate governance contributes to macroeconomic stability and enhances the implementation of sustainable development policies (Halberstam \& Stein 2009). It contributes to the birth of a dependable investment climate domestically and internationally. Further, it signals a regime's devotion to principles of institutions' desire to eradicate corrupt tendencies, providing for advantages that are competitive, and it broadens and deepens local capital markets. Each African country should strive to be identified with international best practices by locating mechanisms or components well suited to their unique capabilities and environments. This enables her to achieve good corporate governance goals that are broad in nature. The trend globally is that good corporate governance has developed as a discipline that stands distinctly alone. Several nations are currently treating it as a fundamental element of economic drive (WB 2008); hence, African states can only ignore it at their own peril.

The Ibrahim Index of African Governance is regarded as the world's most comprehensive ranking of African governance. Figure 1 shows the Mo Ibrahim Index of African Governance as measured in September 2007. It measured sub-Saharan Africa's 48 states on the quality of governance based on safety and security, transparency and corruption, human development, participation and human rights, sustainable economic opportunity and rule of law. The best governed was Mauritius with an overall score of 86.2 , followed by Seychelles 83.1, then Botswana 73.0 with Cape Verde ranking fourth and South Africa fifth (IIAG 2007). The rest of the countries ranked below South Africa as weak performers on the continent of Africa. The indices have not changed significantly of late (IIAG 2017).

According to the 2017 Ibrahim Index of African Governance Report, in 2016, the score for Mauritius declined to 79.4 despite the fact that it remained the best governed in the African continent, Seychelles down to 65.0 and Botswana down to 64.6 (IIAG 2017).

\section{Methodological or analytical approach}

The interpretivist and constructivist paradigm informed this work through a desktop-based study. An interrogation of the 
corporate governance principles in the public sector of selected countries in West Africa and Southern Africa was performed as prompted by the results of the corruption perception indices, WGIs and TI surveys. The responses were used to interpret good corporate governance deficits and construct new knowledge that was generalised and recommended for sustainable development in Africa's public sector as a task ahead.

\section{Literature review}

The Economic Commission for Africa (ECA 2002) and Sebudubudu (2010) describe corporate governance as the means employed in governing or managing privately owned or state-owned enterprises involving relationships between management and stakeholders. It also provides the structure that determines organisational goals and objectives as well as performance monitoring and evaluation mechanisms. Corporate governance structures are less complicated than economic governance in view of the conceptualisation above. The Economic Commission for Africa further describes good governance as the search of goals and objectives by both the board and management seeking to advance the securities of a company and its stockholders by effectively checking and efficiently using available resources (Joiner 2010). A number of factors influence good corporate governance, fundamentally being the legal and institutional frameworks provided by states to bring good governance into existence and effect (Khan 2008; Mkandawire 2007).

As noted by the United Nations Development Programme (UNDP 2009), in trying to bring about good corporate governance, African states have an obligation to primarily provide for an environment that enables all forms of entities that are commercial and non-commercial to grow in predetermined and foreseeable non-selective application of rules (institutional frameworks). Institutions stand as the mechanisms of governance as stated in the World Development Report (WB 2002). Such governance institutions provide parameters for the management of resources while creating value. The created values impact on the performance of the national economy positively. This is illustrated in Figure 2.

It demonstrates how the different public sector values or principles for good governance in the public relate to each other. Principles A and B infiltrate implementation of principles $\mathrm{C}$ to $\mathrm{G}$. It also portrays that good governance is dynamic. This means that the whole entity should be dedicated to improving governance on a continuous foundation in the form of an evaluation process and review. The high-level principles describing good governance in the public sector, the core, as set out below, marry a number of interrelated concepts. For instance, principles $C$ to $G$ are connected to each other by means of the so-called 'plan-docheck-act' cycle. This is also referred to as the Deming Cycle. It is an iterative management process typically used by organisations for the continuous improvement and control of processes and products.

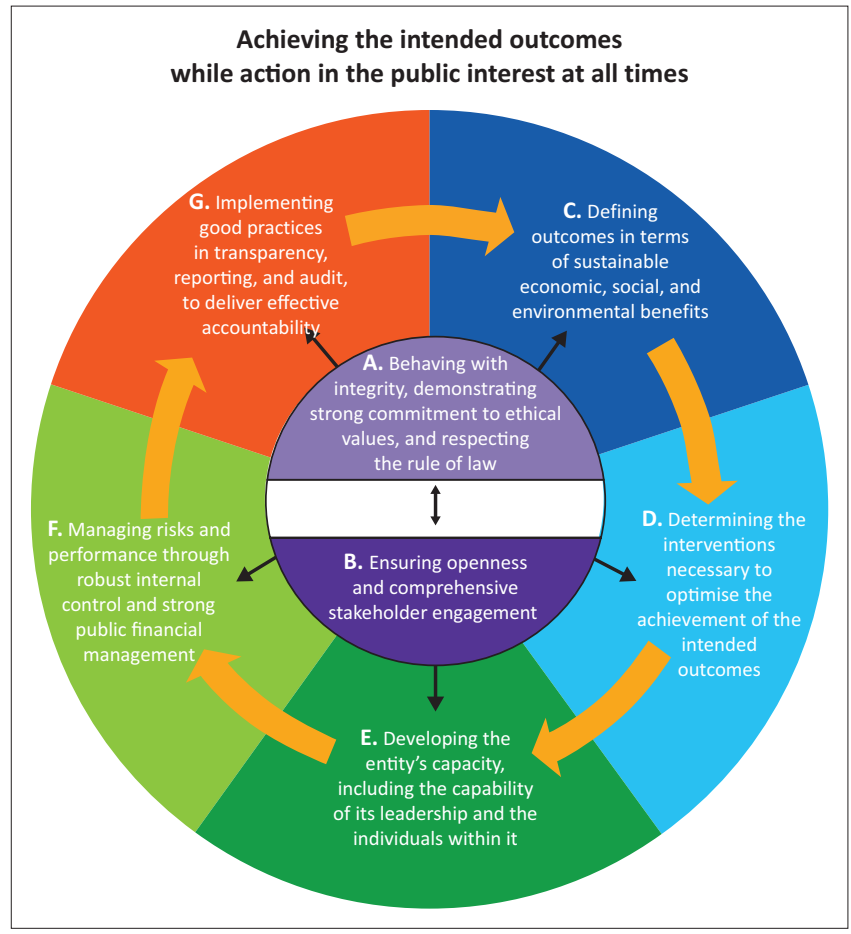

Source: IFAC \& CIPFA (2014:12)

FIGURE 2: Good corporate governance in Africa: A framework illustrating relationships between the principles for good governance in the public sector.

Further to the all-embracing necessities for acting in the public interest at all times in principles A and B, achieving good governance in the public sector also calls for effective arrangements for principles $\mathrm{C}$ to $\mathrm{G}$.

Good corporate governance structure specifically does a profiling of those that make decisions for investment, investments types and the distribution of returns gained. According to a strategy report by the WB (2000), 'Reforming Public Institutions and Strengthening Governance', minority shareholders are less privileged to assert their own stakeholder rights, for example they have great difficulty asserting their shareholder rights particularly in countries whose legal frameworks are weak. The resultant effect is an ownership structure dominated by extremely concentrated proprietorship with limited and minority shareholders (IFAC \& CIPFA 2014). It is further reported that political governance fraught with non-transparent economic and unaccountable practices gives rise to blurred lines between the private and public sectors and bad governance. This is revealed through (ECA 2002) unwarranted state snooping, corrupt tendencies or state capture reflected in 'crony capitalism'.

\section{Why good corporate governance is needed in Africa?}

On average, the continent has been improving in overall governance particularly from 2007 to 2016. An average score of +1.4 points has been recorded from 49.4 (out of 100.0) to 50.8 since the IIAG's first data year 2000 (IIAG 2017). Nevertheless, with an improvement over that decade at an average yearly rate of +0.16 in the last part of this period (the last five years, 2012-2016), the rate of progress fell down 
to an average yearly rate of +0.10 . Africa's slowing overall governance continental trend in the last 10 years (2007-2016) is reflected by variations in performances in the underlying governance categories, as shown in Table 1.

Although general governance progress over the last 10 years (2007-2016) has been driven by improved performance in three of the four governance categories shown in Table 1, namely human development (+4.4), participation and human rights $(+2.2)$ and sustainable economic opportunity $(+1.3)$, more progress could have been realised. This has been hampered because of a decline on average, in safety \& rule of law (-2.4). There is a variation of trends appearing in the last 5 years of this period (2007-2016). Notably, there is still progress in human development and sustainable economic opportunity but at a slower pace. Remarkable progress reflects only in the category of participation \& human rights. On the other hand, deterioration in safety \& rule of law is still present (IIAG 2017). Thus, the last column in Table 1 sadly shows only one category depicting 'increasing improvement' with the rest showing 'slowing improvement' and 'deterioration'.

Good corporate governance is a foundation of competitive advantage and inspires the start-up or repositioning of establishments to a specific republic (Khan 2008).

The reduction of poverty and prompting of economic growth can be triggered by private investment. This is an essential element for creating jobs. Predictable and credible rules contribute immensely through corporate tax to the national fiscus. What is obtaining is a measly $17 \%$ of the gross domestic product (GDP) in sub-Saharan Africa. This gross investment falls remarkably shorter than elsewhere in the world (ECA 2002; Khan 2008). Also, in the world economy, $1 \%$ is accounted for by sub-Saharan Africa. This amounts to an insignificant contribution of foreign direct investment.

Therefore, African states can significantly redirect themselves towards good governance in a bid for rejuvenation, while promoting foreign and domestic investment with affluence. This can also influence the global community at large. It is indisputable that going global is by all intents and purposes a strategic investment that should be embraced by African leaders (Khan 2008). Apart from reaching the world market, globalisation serves as a vehicle for knowledge and technology transfer. This is only possible if the notion that Africa is a bedrock for poor governance is dispelled. As such Africa's leaders should be seized with the demystification of a perception that deflects the inflow of capital away from the continent. One sure way of doing that is the practice of good corporate governance in the public sector. Essentially, globalisation mirrored by the international architecture of finance calls for a corporate governance system that is robust, as noted by UNDP (2000).

The international architecture of finance is determined by key elements including broadening and deepening resident capital markets to entice investors. The United Nations Development Programme (UNDP 2000) argues that capital markets are key drivers of bolstering financial systems and, in turn, contribute to key elements. The international financial architecture is necessary to broaden and deepen local capital markets that attract investors. Capital markets (UNDP 2000) contribute to the strengthening of financial systems which then contribute to financial intermediation internationally and domestically. Ultimately, savings can easily be mobilised and directed to investments that are productive. Viewed from this lens, if the capital markets in Africa should grow, then standards of good corporate governance ought to improve, encouraging and providing investors with assurance for protection. The emerging market economies have indicated that developing countries have an obligation to provide good corporate governance structures to prevent speculative transactions that have been demonstrated by recent financial crises (ECA 2002; UNDP 2000).

It is the prerogative of the African states to create a conducive environment that can promote savings of interests and investment while improving decision-making in all sectors of the economy. To do this, African countries can raise their financial sectors to levels of the international financial architecture. However, the significance of good corporate governance transcends the interests of shareholders' individual corporations because benefits accrue to the state and society at large (WB 1999). It is for this reason that the ECA (2002) concludes that the prelude to improved national economic performance, the effectiveness of overall corporate performance, efficient allocation of capital and monitoring of assets is good corporate governance. On the contrary, corporate misgovernance retards a country's growth economically while reducing its competitiveness on the global market.

\section{Corporate governance factors for African states}

The African Development Bank (ADB 2001) observes that in Africa, there is a significant degree of political influence

TABLE 1: Contrasting governance performance at category level.

\begin{tabular}{|c|c|c|c|c|c|c|c|c|c|c|c|c|c|c|c|}
\hline $\begin{array}{l}\text { Africa(Average scores) } \\
\text { Score } / 100.0 ; 100.0=\text { best }\end{array}$ & 2007 & 2008 & 2009 & 2010 & 2011 & 2012 & 2013 & 2014 & 2015 & 2016 & $\begin{array}{c}\text { Trend } \\
2007-2016\end{array}$ & $\begin{array}{l}\text { Annual } \\
\text { average } \\
\text { trend }\end{array}$ & $\begin{array}{c}\text { Trend } \\
\text { 2012-2016 }\end{array}$ & $\begin{array}{c}\text { Annual } \\
\text { average } \\
\text { trend }\end{array}$ & Trend \\
\hline Overall governance & 49.4 & 49.8 & 49.9 & 50.3 & 50.2 & 50.4 & 50.3 & 50.2 & 50.5 & 50.8 & 1.4 & 0.16 & 0.4 & 0.10 & Slowing improvement \\
\hline Safety and rule of Law & 55.2 & 55.0 & 54.2 & 54.1 & 53.6 & 53.5 & 52.5 & 52.1 & 52.0 & 52.8 & -2.4 & -0.27 & -0.7 & -0.18 & Slowing deterioration \\
\hline Participation and human rights & 47.2 & 47.1 & 46.9 & 47.5 & 48.0 & 48.4 & 48.8 & 48.8 & 49.4 & 49.4 & 2.2 & 0.24 & 1.0 & 0.25 & Increasing improvement \\
\hline Sustainable economic opportunity & 43.8 & 44.4 & 45.0 & 45.3 & 44.7 & 44.7 & 44.9 & 44.4 & 44.8 & 45.1 & 1.3 & 0.14 & 0.4 & 0.10 & Slowing improvement \\
\hline Human development & 51.7 & 52.4 & 53.3 & 54.1 & 54.3 & 54.8 & 5.0 & 55.4 & 55.8 & 56.1 & 4.4 & 0.49 & 1.3 & 0.33 & Slowing improvement \\
\hline
\end{tabular}

Source: IIAG Index Report (2017:18) 
across countries on the dynamics of good corporate governance. These political factors that influence good corporate governance vary in magnitude and direction. For instance, Botswana is portrayed on the international forum as Africa's shining example of good corporate governance punctuated with sound economic policies. Yet, for its neighbours, Zimbabwe and Malawi among other countries, the situation has not been rosy, where separation of administrative capacity and institutional weaknesses from governance issues sometimes appear absurd.

The ADB (2001) also observes that a dearth of commitment from government does not necessarily stand as a reflection of poor governance. It may still not be easy to eliminate corruption from within the rank and file of the bureaucratic machinery even though political leadership is perceived as honest and strong. Nonetheless, Amoako (2000) argues that weak political leadership is often co-located with bad practices of corporate governance. This means usually strong political leadership tends to be co-located with good practices of corporate governance. For Amoako, all forms of good governance that obtain in society are influenced by strong and honest political governance mechanisms.

The Economic Commission for Africa (ECA 2002:8) defines strong and honest political governance as a social state exemplified by, among other things, open, predictable and progressive policy-making; a bureaucracy filled with a specialised ethos; a robust civil society contributing to public affairs; observance of the rule of law, reverence for basic human rights and freedoms and judicial independence; dependable traditions and predictable institutions that regulate how power and authority are exercised. These include (1) the procedure for governments' selection, how they are accountable to the public, how they are monitored and how they are replaced, (2) the ability of governments to account for resources competently, and apply comprehensive strategies and (3) the reverence of people and the management for the organisations.

Also, the safeguarding of a political order is (1) sincere, enjoying the support and loyalty of the people, (2) able to defend the sovereign interests of the people, (3) able to meet the fundamental interests of the people, (4) able to engage other global players that describe the world economy and (5) ability to diminish internal and cross-border conflicts.

Yet, on the continent, the subversion of basic human rights and freedoms coupled with bad political governance have usurped the potential economic growth and sustainable development to quite a number of countries (Utz 2007). Therefore, supranational bodies such as the African Union (AU), Common Market for Eastern and Southern Africa (COMESA), Southern African Development Community (SADC), African Development Bank (ADB) and Development Bank of Southern Africa (DBSA) among others have a duty to ensure that they capacitate those states that have remarkably fallen victim of not only poverty but also bad governance.
This is benchmarked (Grzeszczak 2015) against the European Union (EU) and the European Social Fund (ESF). Shleifer and Vishny (1997) argue that vital to the interface between political governance and corporate governance is the capability to offer obligatory institutional frameworks for supporting outcomes of good governance by the state.

\section{Institutional reforms}

Considerable capacity building and reforms are needed if Africa's public sector institutions are to operate effectively and efficiently. According to ECA (2002:9), reforms are needed in the following areas:

- civil services and its administration;

- improving parliamentary oversight;

- supporting participatory decision-making;

- implementing effective measures to combat corruption and embezzlement;

- judicial reforms.

These are tersely discussed below.

\section{Administrative and civil services}

In most African countries, the public service sector tends to have fairly large numbers of employees exceeding the capacities of those countries. As a result, they also tend to be much costly, less productive and effective than expected (Oyekan 2009; Shahada 2010). Furthermore, agencies and ministries become ill-equipped and poorly structured. These characteristics on the continent have presented a fertile ground for bureaucratic corruption and bad governance (Emery 2000). In some countries, this has made corruption official rather than having officials who are corrupt. It becomes a norm for the public to pay a bribe in order to access government services. Besides bribery, unlawful enrichment, fraud and embezzlement at the expense of the taxpayer takes centre stage (DFID 2000). Therefore, reforms here must entrench aspects of integrity, honesty, transparency and accountability among others.

Studies across the world reveal that one of the prerequisites of good governance is a civil service that is skilled for the job, motivated and guided by professional ethos and values, although this should be complemented by other factors as it is not sufficient in itself (Gray \& Khan 2010; Khan 2008; WB 2007). The CIPFA in collaboration with the International Federation of Accountants (IFAC)'s draft of 2013 contends that empirical evidence provides that a very bad civil service breeds bad governance, although the right to accountability and other mechanisms may be in place.

\section{Oversight by parliament}

Parliament is one of those institutions with a mandate to hold the executive branch of government accountable, oversight of government and other authorities and act as a counterbalance to executive power (Johnson \& Nakamura 1999). However, from the 20th century, there appear to have 
been a constant drop in the power of several parliamentary bodies. This has resulted in inadequacies of oversight impact on state affairs and the executive. In cases where there is strong representation in parliament by the opposition parties in Africa, for reasons mainly of controlling state resources, the executive dictates appointment of cabinet members based on loyalty rather than ability.

In this case, loyalty to individual political parties outweighs the need for legislative members to abide by the legislative institution especially in the ruling parties. As a result, Mbaku (1997) contends that these parliamentarians, in most cases, 'rubber stamp' decisions from cabinet without applying their minds negating their oversight roles. Yet, effective legislatures should contribute to good governance and sustain democracy. To enhance oversight by parliament and performance in Africa, there may be need for a good will and buy in reposed in members of the legislature irrespective of political affiliation to promote good governance. Adequate funding may be required to capacitate parliamentarians so that they improve the process of parliamentary oversight. Most of the members of parliament assume office without rudimentary knowledge of the parliamentary oversight roles except knowledge of allegiance to their party and constituencies (Mbaku 1997).

The dearth of political will render anti-corruption laws inoperable. It is defiance of logic when senior government parliamentarians get arrested on charges of corruption, fraud and perjury, yet these members should be exemplary (Johnson \& Nakamura 1999). Parliamentarians ought to work in unison regardless of petty party politics in pursuit of the integrity that the parliamentary agenda provides to them. In Africa, because of political polarisation, it is inconceivable how this can be achieved. Perhaps, those more level headed and enlightened parliamentarians may take the lead with support from regional economic communities such as the SADC and the Economic Community for West Africa States (ECOWAS). Independent agencies can play a complementary watchdog role in collaboration with civil society and faith-based organisations. If truly independent, such complementary agencies may be used to gather information that would not be easily availed to parliament.

\section{Decision-making that is participatory}

One key component of good governance is that of participatory decision-making. Citizens and other stakeholders through their participation in decision-making processes enjoy a sense of belonging. This empowers them to demand accountability and transparency from government. However, for purposes of good governance, more states should promote better participatory decision-making as a gesture of inclusive democracy. For instance, Hamdok (2001) argues that electoral democracy remains problematic in Africa as prospective voters get disenfranchised. The example from Botswana is encouraging. There is no single constitutional amendment that can be performed by parliament without subjecting such an amendment to a referendum. The citizenry have to vote 'yes or no' to the proposed amendment.

\section{The battle against corruption}

Hope and Chikulo (1999) observed that governance malpractices in Africa have become deep rooted, cancerous and legendary. As a result, some societies have lived to believe that 'kickbacks' are part of governance practices. But, the problem is not only typical of African governance as it has become a global concern as well. The battle against eruption of corruption in Africa has seen the establishment of antigraft commissions and whistle-blowers, with voluminous literature to that effect (Joiner 2010; Mkandawire 2007; Rose-Ackerman 2001; UNDP 2009). However, the difficulty that occurs today is less on the effort to fight corruption, but lack of executive political support. For instance, the case of Zimbabwe's reported cases by the Auditor General in early 2017 in which the executive ignored the audit report completely.

Many programmes to combat corruption have suffered too much political interference despite having the backing of statutes. The question at hand is more about engendering the apparatus to activate and cultivate political will as this appears to be lacking. It has been an exhortation by the African contributors way back at a World Bank Institute programme on 'Controlling Corruption' as reported in Towards Collective Action to Improve Governance and Control Corruption in Seven African Countries in 1999 (WB 1999). This led to the disbandment of some anticorruption measures in favour of corrupt innuendoes in other countries. Undoubtedly, it is a must for political will to prevail in combating graft supported by leadership of high integrity in Africa.

It is for this reason that Rose-Ackerman (2001) views the potential to exterminate or curb corruption as residing more in good governance. According to UNDP and OECD (1998), political will denotes a demonstrable dependable resolve by political actors to uproot perceived or real causes and effects of graft at a systemic level. This may be a critical and sustainable starting point to fight corruption, or else the statements of states may merely be regarded as rhetoric and ritualistic.

\section{Reforming the judiciary system}

Judicial reform in Africa (WB 2001) for purposes of realising good governance is required in order to produce and preserve judicial independence. The pillar of the rule of law is judicial independence whose tenets are impartiality, respect and independence. This means that judgements should be made without fear or favour. Once judgements are handed down, they ought to be respected without prejudice to the judge's rights. As the ECA (2002) puts it, based on the foregoing characteristics, the modest meaning of judicial independence is the insulation of the judicial procedures and practices against any opinionated force to sway the conclusions of cases in favour of litigants or accused.

While powerful elites may try to influence the judicial process financially or socially, the most serious threat is posed by governments to the judicial independence of some 
African states. Sadly, for instance in Zimbabwe, some judgements against the state's land reform were disregarded and the judges who made such judiciary decisions lost their jobs. World Bank (2001) notes that there are recognised endeavours by regimes to sway judicial decisions on the continent ranging from bribery, harassment, dismissals and transfers to promotions. Governments have also been known to meddling in the assignment of cases to judicial practitioners or complete removal of cases from courts placing them to some tribunals that have no penchant to follow due process.

\section{Corporate governance components for African states for sustainable development}

Developing economies now identify the need for an economical corporate segment as crucial for growth and development. Africa must guarantee the investor community that, what they plough in will be safe and managed efficiently on the strength of accountability and transparency. That assurance is only through good corporate governance. But African countries are often not well equipped to implement the corporate governance systems because of their political systems and excessive political decisions that are handed down as directives from political bigwigs. As noted by Lazonick and O'Sullivan (2000), among the major constraints in this respect are the corporate sector's ownership structure, the financial sector's interlocking relationships with government, weak judiciary and legal systems, coupled with limited capabilities of human resource.

In terms of best practices, the improvement of good corporate governance would entail (ECA 2002:34):

- a legal framework to deal with stated rights and obligations of a company, including its directorship, shareholding and related stakeholders. Provision for the effective application of the law as well;

- mechanisms put in place for a corporate governance culture;

- a conducive environment for good corporate governance created by promoting financial disclosure requirements as well as good ownership structures;

- provision of arrangements that facilitate supervision while encouraging the adoption of sound practices of corporate governance;

- capacity building in corporate governance via in-service training and educational programmes to all levels for improving management and performance.

Although the thrust on corporate governance has hinged on the private sector, the same can be directed upon the public sector. Developments in privatising state-owned enterprises have been encouraging but the task is far from being completed. Several African states do have a considerable assortment of government owned enterprises.

If they decide to dispose of them or not, what is useful is the corporate governance of these enterprises, irrespective of the ownership structure. To ensure corporatisation of state-owned enterprises (SOEs), the WB cited in ECA (2002:35) recommended that enterprises:

- Submit to commercial law functioning.

- Assume one corporate form.

- Open communication and be credible in operations.

Africa is obliged to consider these recommendations seriously for sustainable development.

\section{Standards and codes for good corporate governance in Africa}

The adoption of these standards should be seen as an important element in stimulating good corporate governance as this is viewed more favourably by international investors. The justification of these standards is the same worldwide. While there are 70 codes for corporate governance, the key ones are discussed in this article as given by the International Monetary Fund (IMF 2001).

\section{The code of good practices on fiscal transparency}

Provisions include: roles and responsibilities that are clear, availability of public information, transparent budget preparation and execution and assurances of independent integrity:

- Roles and responsibilities that are clear: The public sector should be visibly distinguished from the rest of the economy, with well-defined policy and management roles.

- Availability of public information: Governments must be committed to the publication of fiscal information timely.

- Transparent budget preparation and reporting: This means that budget data should be presented in such a way that it facilitates policy analysis while promoting accountability.

- Assurances of independent integrity: There should be unquestionable integrity.

In order to promote sustainability and development, there is need for fiscal information integrity which should be subjected to independent public scrutiny. Fiscal discipline is one area which African states ought to embrace as highlighted above. Indiscipline in this area tends to cause untoward suffering of those governed. Where discipline abounds, bulleted issues above can forge a semblance of sustainability and development.

\section{The monetary and financial policies code}

The code depends on two simple principles: firstly, policies are made more effective when the public is well informed about the goals and if central banks together with financial agencies make a reliable promise to meeting them; secondly, good governance requires that central banks together with financial agencies are accountable, more so if these agencies enjoy a high degree of autonomy.

\section{Guidelines for public expenditure management}

Four forms of fiscal and financial discipline are required for public expenditure management to be effective: 
- consistency with the macroeconomic constraints, which implies the controlling of aggregate expenditure to safeguard affordability;

- resource allocations reflecting expenditure policy priorities;

- delivery of public services efficiently;

- efficient budget execution and debt management practices.

These forms may enhance public expenditure management if fully implemented and lead to sustainable development.

\section{Making priority standards of good governance practices for Africa}

Formulating a prioritised list of codes and standards for other countries may be a relatively simple matter. In Africa, the exercise can be much more demanding. This is because of the diversity of the continent's countries economically and politically. For example, South Africa has much higher institutional developments than in Zimbabwe. In many African countries, the logic is that the more affluent can circumvent the bad governance through other means like bribery. The less privileged are unable to bear the costs of bad governance and yet constitute the majority of African society. Priority should be directed to best practices that bring forth pro-poor outcomes with the eradication of poverty being the ultimate goal. With this in mind, the codes and standards should be prioritised to consolidate democracy and promote market efficiency through good governance practices.

\section{Discussion of findings and results}

The main findings reveal that the sizes of the civil service are bigger in comparison to the countries' population, the judiciary are less independent than expected and corruption levels are relatively high while participatory decision-making is low with weak parliamentary oversight. While some basic tenets of corporate governance in the public sector are employed, the effectiveness tends to be weakened by excessive political decisions that are handed down as directives from political bigwigs. The task ahead among others in the public sector is that of evading these 'excesses' which board of directors in the private sector are less predisposed to employ, in pursuit of good corporate governance practices.

\section{Recommendations}

For good corporate governance, African states must undertake the following among other things:

- Short term

- to signal a departure from excessive political decisions;

- to strengthen current good corporate governance structures.

- Medium term

- to implement in an accountable manner public management functions;

- to create a working environment which attracts both domestic and international investors.

- Long term

- to demonstrate a desire to achieve high levels of good corporate governance practices that promise sustainable development;

- to implement poverty reduction and development policies.

The foregoing creates a foundation that may enhance reduction of poverty, accelerate economic growth and provide for sustainable development in Africa. The proposed implementation process is shown in Figure 3 for a desired outcome.

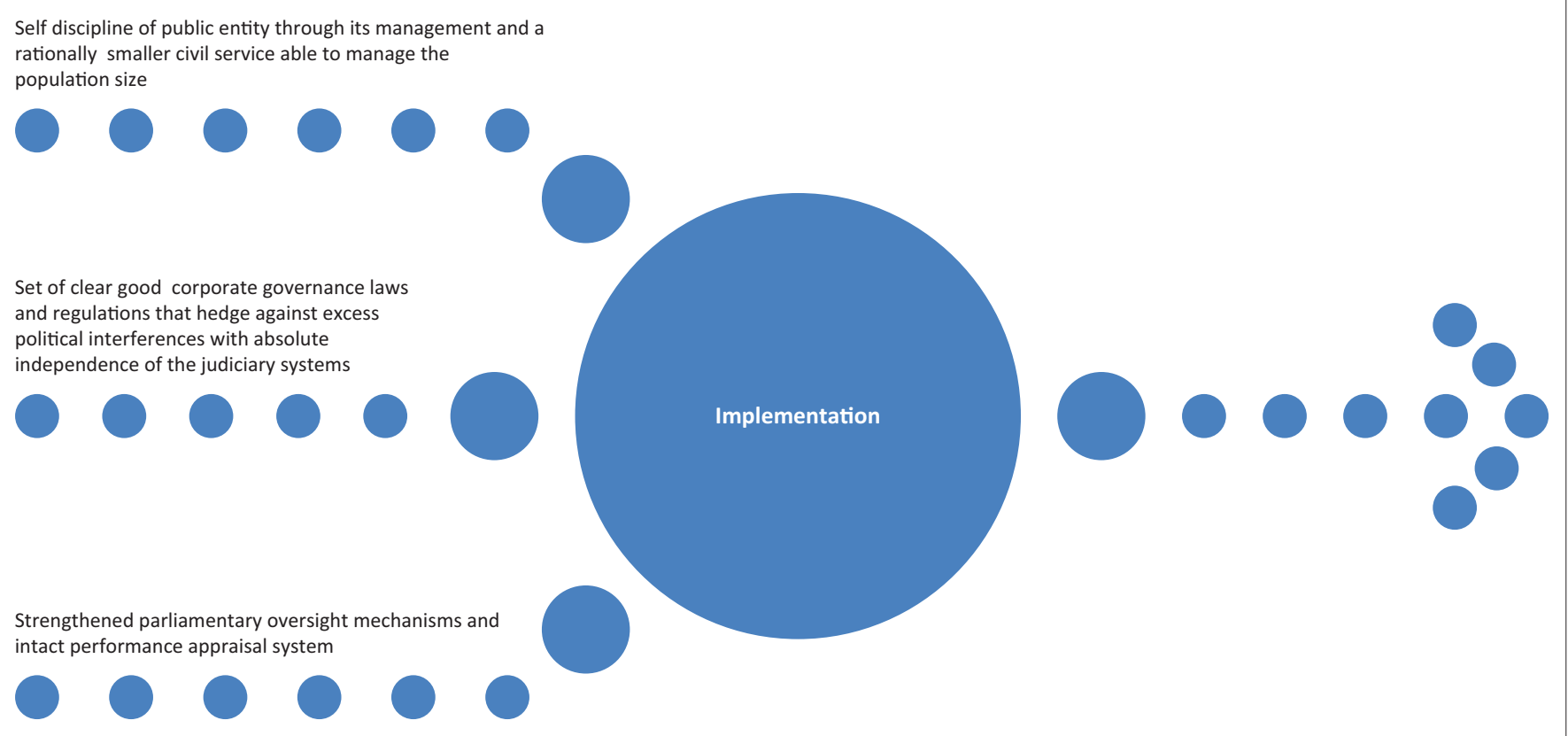

FIGURE 3: Public sector good governance implementation process framework. 
The short- to long-term good corporate governance strategies for the public sector could be implemented as above for sustainable development as the task ahead for Africa.

\section{Conclusion}

While concerted efforts are directed towards good corporate governance in the private sector, more should be performed in the public sector by subjecting state enterprises to commercial law functioning. Good corporate governance is good for Africa if sustainable development is to thrive. The application of rules and policies predictably and fairly by a state attracts more domestic and foreign investment. Effective institutions and efficient markets are indispensable if African countries are to ensure sustainable development. Problems of corruption, weak and ineffective governance do not attract both domestic and international investors. It is imperative that African states develop political will, influenced by those enlightened leaders, and come to terms with policy agenda that fosters good corporate governance. While this may be a political process, the challenge in Africa is one of determining if, indeed, governments are there to rule for narrower interests or for the public good. As such African leadership is challenged to use the political space which they occupy to influence development of good corporate governance policies for sustainable development as suggested in this article. The task ahead for sustainable development in Africa's public sector is for African countries to redirect their efforts in applying good economic and corporate governance practices as highlighted herein.

\section{Acknowledgements Competing interests}

The author declares that he has no financial or personal relationships which may have inappropriately influenced him in writing this article.

\section{References}

ADB, 2001, African development report 2001: Fostering good governance in Africa, Oxford University Press, New York.

AGGN, 2010, Addressing good governance in Africa, African Good Governance Network, Bonn, Germany.

Amoako, K., 2000, Perspectives on Africa's development, United Nations, New York.

AUC, 2015, AGENDA 2063:The Africa we want - a shared strategic framework for inclusive growth and sustainable development, The African Union Commission, s.l.

CIPFA \& IFAC, 2013, Good governance in the public sector - A consultation draft for international framework, viewed 02 October 2017, from http://www.ifac.org

DFID, 2000, Strategies for achieving the international development targets: Making government work for the poor, Department for International Development, London.

ECA, 2002, Guidelines for enhancing good economic and corporate governance in Africa, Economic Commission for Africa, s.l.

Emery, J., 2000, Administrative barriers to foreign investment: Reducing red tape in Africa, World Bank, Washington, DC.

Gray, H. \& Khan, M., 2010, 'Good governance and growth in Africa: What can we learn from Tanzania?', in V. Padayachee, (ed.), The political economy of Africa, pp. 339-356, Routledge, London.

Grzeszczak, R., 2015, 'The concept and practice of good governance in the European Union', International Journal of Law and Political Sciences 9(2), 449-453.
Halberstam, D. \& Stein, E., 2009, 'The United Nations, the European Union, and the of Sweden: Economic sanctions and individual rights in a plural world order', Common Market Law Review 46, 60 .

Hamdok, A., 2001, Governance and policy in Africa, United Nations University/World Institute for Development Economics Research, Helsink.

Hope, K.S. \& Chikulo, B., 1999, Corruption and development in Africa, Macmillan/ Palgrave, London.

IFAC \& CIPFA, 2014, International framework: Good governance in the public sector, International Federation for Accountants and Chartered Institute of Public Finance and Accountancy (CIPFA) CIPFA, New York.

IIAG, 2007, 2007 Ibrahim index for Africa governance, viewed 28 March 2008, from http://www.moibrahimfoundation.org/

IIAG, 2017, 2017 Ibrahim index of African governance, Mo Ibrahim Foundation s.l., viewed 16 December, from http://s.mo.ibrahim.foundation/u/2017/11/ 21165610/2017-IIAG-Report.pdf?ga =2.193655854.22158350.1531665894329198210.1531665894

IMF, 2001, Fiscal reforms in low-income countries, International Monetary Fund, Washington, DC.

Jobbins, M., 2017, 'We need to learn from recent crises in West Africa: Local governance and civil society solutions, in A. Sy \& C. Golubski (eds.), Upholding good governance: Democracy, elections, and local institutions, pp 94-97, Global Foresight Africa, s.I.

Johnson, J. \& Nakamura, R., 1999, A concept paper on legislatures and good governance, viewed 23 August 2017, from http://www.magnet.undp.org/docs/ governance, viewed 23 August 2017 , from http://www.magn
parliaments/concept $\% 20$ paper $\% 20$ revised $\% 20$ MAGNET.htm

Joiner, J., 2010, Welcome statement by Mrs. Julia Dolly Joiner, Commissioner for Political Affairs African Union Commission. African Governance Platform Meeting, 2nd August 2010, viewed 30 July 2017, from www.googlesyndicatedsearch 2nd August 2010, viewed 30 July 2017, from wwW.googlesynd

Khan, M., 2008, 'Governance and development: The perspective of growth-enhancing governance', in GRIPS development forum (ed.), Diversity and complementarity in development aid: East Asian lessons for African growth, Tokyo, viewed 04 August 2017, from http://eprints.soas.ac.uk/9853/1/GRIPS.pdf

Lazonick, W. \& O'Sullivan, M., 2000, Perspectives on corporate governance, innovation, and economic performance, The European Institute of Business Administration, Fontainebleau.

Mbaku, J., 1997, Institutions and reform in Africa, Praeger Publishers, Westport, CT.

Mkandawire, T., 2007, 'Good governance: The itinerary of an idea', Development in Practice 17(4), 679-681. https://doi.org/10.1080/09614520701469997

Oyekan, A.O., 2009, 'Democracy and Africa's search for development', The Journal of Pan African Studies 3(1), 214-226.

Rose-Ackerman, S., 2001, 'Political corruption and democratic structure', in A.K. Jain (ed.), The political economy of corruption, pp. 35-62, Routledge, London.

Sebudubudu, D., 2010, 'The impact of good governance on development and poverty in Africa: Botswana - A relatively successful African initiative', African Journal of Political Science and International Relations 4(7), 249-262.

Shahada, O., 2010, Who are Africans?, viewed 29 January 2018, from www. africanexecutive.com/modules/magazine/articles.php?article $=5292$

Shleifer, A. \& Vishny, R., 1997, 'A survey of corporate governance', Journal of Finance 52, 737-783. https://doi.org/10.1111/j.1540-6261.1997.tb04820.x

TI, 2008, Transparency international 2008. Corruption perceptions index 2008, viewed 17 August 2017, from http://www.transparency.org/policy_research/surveys_ indices/cpi/2008

UNDP, 2000, Budgets as if people mattered: Democratizing macroeconomic policies, UNDP, New York.

UNDP, 2009, Human development report, viewed 03 August 2017, from http:// hdrstats.undp.org/en/countries/country_fact_sheets/cty_fs_BW

UNDP \& OECD, 1998, Corruption and integrity improvement initiatives in developing countries, UNDP, New York.

Utz, R., 2007, Sustaining and sharing economic growth in Tanzania, The World Bank, Washington, DC.

VC, 2011, European commission for democracy through law, Venice Commission Study no. 470 / 2008, The Venice Commission for the Council of Europe, Strasbourg.

WB, 1999, Towards collective action to improve governance and control corruption in seven African countries, viewed 23 August 2017, from http://www.worldbank. org/wbi

WB, 2000, Reforming public institutions and strengthening governance, Washington, DC, World Bank.

WB, 2001, Initiatives in legal and judicial reform, World Bank, Washington, DC

WB, 2002, World development report 2002: Building institutions for markets, Oxford University Press, New York.

WB, 2007, Governance, viewed 02 October 2017, from http://go/worldbank.org

WB, 2008, Worldwide governance indicators (WGI), The World Bank Institute, Washington, DC.

WDI, 2016, Staistical yearbook, World Banks' World Development Indicators, Washington, DC

WHO, 2016, Management of Ebola in West Africa, World Health Organisation, Washington, DC 